\title{
Ameliorative effect of methanol extract of Telfairia occidentalis Hook. and Amaranthus hybridus Linn. against cadmium induced oxidative stress in rats
}

\author{
Ejiofor U. Emmanuel ${ }^{*}$, Ebhohon S. Onagbonfeoana ${ }^{2}$, Nwuke P. Chinedu ${ }^{2}$, Atasie O. Chibuike ${ }^{2}$, Oriaku C. Edith ${ }^{2}$, \\ Ineama Chioma ${ }^{2}$, Ajah Obinna ${ }^{2}$, Ikechukwu C. Gavin' ${ }^{2}$, Ibeh C. Raymond ${ }^{2}$, Omeh Y. Ndukaku ${ }^{2}$ \\ ${ }^{1}$ Department of Biochemistry, Faculty of Sciences, Clifford University, Owerrinta, Abia, Nigeria. \\ ${ }^{2}$ Department of Biochemistry, College of Natural Sciences, Michael Okpara University of Agriculture, Umudike, Umuahia, Abia State, Nigeria.
}

\section{ARTICLE INFO}

Article history:

Received on: 16/06/2017

Accepted on: 06/08/2017

Available online: 30/09/2017

\section{Key words:}

ALT, Catalase, Proteins, GSH, Vegetables.

\begin{abstract}
Oxidative stress caused by cadmium in living systems leading to various clinical interpretations has been well documented. The study investigated if methanol extract of Telfairia occidentalis and Amaranthus hybridus could ameliorate the toxicity caused by cadmium. Administration of cadmium lead to an increase in lipid peroxidation marker MDA $0.42 \pm 018,1.66 \pm 1.13$ and reduced the concentration of enzymatic antioxidants SOD $10.22 \pm 2.13,10.92 \pm 0.54$, Catalase $22.82 \pm 14.74,19.90 \pm 1.16$ and GSH $18.02 \pm 0.49,12.89 \pm 085$ in liver and kidney of the rats. Result for liver function assay showed a significant increase in AST $24.00 \pm 3.31$, ALT $60.40 \pm 10.85$ and ALP $78.05 \pm 15.75$ in the serum of rats administered cadmium without treatment. Total protein concentration was significantly higher in the vegetable treated group when compared to the group administered cadmium without treatment $3.72 \pm 041$. Kidney function assay, creatinine and urea were significantly high in the rat administered cadmium without treatment when compared to the rats that received the vegetables. Phytochemical screening showed the presence of flavonoids, phenols, alkaloid in high concentration in the vegetables. In vitro antioxidant reflected high radical scavenging activity. From the result of this study, the vegetable showed robust ameliorative effect on cadmium induced toxicity which can be labelled to the rich antioxidant content of the vegetables and also the ability of the vegetable to promote phase 2 bio-transformation of xenobiotic.
\end{abstract}

\section{INTRODUCTION}

Cadmium is a heavy metal present in the environment and causes serious environmental and occupational hazard to human (Tarasub et al., 2008). Cadmium causes lipid peroxidation by stimulating the production of superoxide anions and inhibits antioxidants such as superoxide dismutase and glutathione peroxidase, causing accumulation of free radicals that damage the cells and produce chronic disease (Amara at al., 2011).

* Corresponding Author

Ejiofor Emmanuel, Department of Biochemistry, Faculty of Sciences, Clifford University, Owerrinta, Abia, Nigeria. Ph: (+234) 7036250103

Email: ejioforemmanuelbiz @ gmail.com
Cadmium affects cell proliferation, differentiation, apoptosis and other cellular activities (Yuan et al., 2013). Cadmium is readily available in industrialized regions of the world. Studies by Ejiofor et al. (2016) showed accumulation of cadmium in water bodies around oil refinery and cement regions in Southern Nigeria. In previous literature, cadmium toxicity is associated with several clinical complications, renal dysfunction, bone diseases, hepatic dysfunction, with renal tubular damage is probably the most common adverse effect. Studies have shown that it toxicity is dose dependent, route of exposure and time (Jarup at al., 2000). The liver is also a point of cadmium toxicity, leading to apoptosis and necrosis (Lopez et al., 2003). The International Agency for Research on Cancer has classified cadmium a potent human carcinogen. 
Practitioners of traditional medicine believe that the constituents of plants are distinctive as they contain active compounds that are crucial in enhancing the well-being of their patients. The ignited interest in the pharmaceutical importance of plants has led to the discovery and adoption of plant extracts which were commonly used in traditional medicine, as alternative source of remedy (Ekaiko et al., 2015). Dietary antioxidants are useful because of their protective roles against oxidative stress involved in the pathogenesis of diseases such as anaemia, diabetics, cardiovascular diseases and most prevalent cancer.

Telfairia occidentalis is a tropical vine grown in Nigeria as a leaf vegetable. The plant is commonly known as fluted gourd, fluted pumpkin, and ugu (Akoroda, 1990). The Telfairia occidentalis has been traditionally used in Nigerians as a cure for fatigue and diabetes (Alada, 2000). The high rich iron content of the leaves is employed in boosting blood of lactating and pregnant women (Okoi and Mgbeogu, 1983). Flour produced from the seeds can be used for high-protein breads (Emebiri and Nwufo, 1990). The vegetable $T$. occidentalis can also be prepared for herbal medicine, it is used to treat sudden attack of convulsion, malaria, and anaemia; it also plays a vital and protective role in cardiovascular diseases (Badifu, 1993). Two important antioxidant compounds that have been isolated and elucidated from $T$. oidentallius include; Kaempferol-3-O-rutinoside and Kaempferol. Amaranthus hybridus is a species of flowering plant in the amaranth genus. It is commonly known as careless weed, dioecious amaranth, it is edible and highly nutritious (Culpepper, 2006). Suffo et al. (2016) reported that A. hybridus is rich in phytol, squalene and 1- Eicosanol. In Nigeria, these vegetables have been prepared collectively as a component of food.

Considering the use of these vegetables in folklore medicine and for nutritional purposes, the study investigated of methanol extract of the vegetables could be useful in ameliorating toxicity induced by cadmium in rats.

\section{MATERIALS AND METHODS}

\section{Plant material}

The vegetables were collected from a Farm in Arochukwu Area of Abia State, Nigeria. The plants were identified by Dr. Garuba Omosun of the Department of Plant Science and Biotechnology, Michael Okpara University of Agriculture Umudike, as Telfairia occidentalis and Amaranthus hybridus and were issued specimen number MOUAU/COLNAS/ $\mathrm{PSB} / 15 / 215$ and MOUAU/COLNAS/PSB/ 15/216 respectively. The plant materials were obtained in the month of October, 2016.

\section{Plant extraction}

The leaves of Telferia occidentalis and Amaranthus hybridus were washed with running water to remove sand and debris. The leaves were chopped into small pieces, air-dried for five days under shade at room temperature and pulverized using an electronic blender. The dried and pulverized leaves were extracted by cold maceration method for 72 hours at room temperature using methanol (Sigma- Aldrich) in a winchetser bottle (Sukhev, 2008). The mixture was filtered with Whatman No. 1 filter paper. The filtrate was concentrated using vacuum rotary evaporator at $40^{\circ} \mathrm{c}$ to give residue. The extract was stored in refrigerator at $4^{\circ} \mathrm{c}$.

\section{Phytochemical test}

Concentration of flavonoids, tannins, cyanide, alkaloids and phenols in the extracts were determined by the method described by Harborne (Sukhdev, 2008) and Edeoga et al. (2005)

\section{In vitro antioxidant}

In vitro antioxidant activity was achieved using 2, 2Diphenyl-1-picrylhydrazyl (DPPH) photometric assay as described by Mensor et al. (2001). The ferric reducing antioxidant power was carried out as described by Benzie and Strain, (1999).

\section{Experimental animals}

Wistar albino rats were used for this study. The animals were obtained from the animal house of the Department of Veterinary Medicine, Michael Okpara University of Agriculture, Umudike. They were kept in aluminium cages in a well-ventilated room, fed with standard pelleted grower feed (Vital Feed, Nigeria) with access to clean drinking water. They were kept at normal environmental temperature. The animals were maintained in accordance with the recommendation of the Guide for the Care and Use of Laboratory Animals (NIH, 2002). The animals were allowed one week for acclimatization. Ethical approval was obtained from the Ethical Committee of the Department of Biochemistry, College of Natural Sciences, Michael Okpara University of Agriculture, Umudike, and was given ethical approval number BCH/ETH/16/035.

\section{Toxicity testing $\left(\mathrm{LD}_{50}\right)$}

The acute toxicity of cadmium chloride $\left(\mathrm{Cdcl}_{2}\right)$ was determined by single oral administration of $\mathrm{Cdcl}_{2}$ ranging from $150 \mathrm{mg} / \mathrm{kg}$ to $300 \mathrm{mg} / \mathrm{kg}$ body weight. The animals were observed for signs of toxicity for 72 hours after administration. $\mathrm{LD}_{50}$ values calculated showed $212 \mathrm{mg} / \mathrm{kg} \mathrm{B}$.W of $\mathrm{Cdcl}_{2}$ as toxic dose.

\section{Experimental design and animal grouping}

Twenty-five animals were randomly distributed into five groups of five animals per group. The weight of the animals was checked during distribution to ensure a weight difference of $+/-5$ inter and intra cages.

Group A served as the control group and received distilled water only.

Group B received $50 \mathrm{mg} / \mathrm{kg}$ body weight of cadmium chloride once every two days and received $300 \mathrm{mg} / \mathrm{kg}$ of Telferia occidentalis extract daily

Group C received $50 \mathrm{mg} / \mathrm{kg}$ body weight of cadmium chloride once every two days and received $300 \mathrm{mg} / \mathrm{kg}$ of Amaranthus hybridus extract daily 
Group D received $50 \mathrm{mg} / \mathrm{kg}$ body weight of cadmium chloride once every two days and received $300 \mathrm{mg} / \mathrm{kg}$ of Telferia occidentalis and Amaranthus hybridus combined in equal grams daily.

Group E received $50 \mathrm{mg} / \mathrm{kg}$ body weight of cadmium chloride once every two days.

Experimental period lasted for twenty-one days, after which blood samples were collected through retro-orbital venous plexus. Blood was spun at $895 \mathrm{xg}$ for 10 mins to obtain serum. The animals were later euthanized and the liver and kidney were dissected out immediately for preparation of liver and kidney homogenate used in antioxidant assay.

\section{Biochemical estimation}

\section{Liver enzyme parameters}

Aspartate aminotransferase (AST) and alanine transaminase (ALT) were done by the method described by Reitman and Frankel, (1957). Alkaline phosphatase (ALP) was described by the method described by Klein et al. (1960), using Randox test kits (Randox Laboratories, UK). Serum total protein was assayed using standard diagnostic kit (Randox Laboratories, UK).

\section{Liver and kidney tissue preparation}

Phosphate buffer $(9 \mathrm{ml})$ was added to one gram of liver and kidney tissue in well labelled organ bottles. The mixture was homogenized and centrifuged at $1000 \mathrm{x} \mathrm{g}$ for 5mins. The supernatant was separated from the pellet and labelled the aliquot. This was used for antioxidant assay.

\section{In vivo antioxidant}

\section{Estimation of catalase activity}

Catalase activity in liver and kidney homogenate was determined using the modified method described by Atawodi, (2011).

\section{Estimation of SOD activity}

Superoxide dimutase (SOD) activity in liver and kidney homogenate was determined by the method described by Sun et al. (1988)

\section{Determination of lipid peroxidation}

The level of thiobarbituric acid reactive substance (TBARs) and malondialdehyde (MDA) production in liver and kidney homogenate was determined by the method described by Draper and Hadley, (1960).

\section{Determination of reduced gluthathione}

GSH activity in liver and kidney homogenate was determined using method described by Owen and Belcher, (1965)

\section{Kidney function parameter}

Creatinine and urea concentration was determined using Randox commercial kits from Randox Laboratories, UK.

\section{Statistical analysis}

Data obtained were statistically analysed using one-way analysis of variance (ANOVA) followed by Duncan post hoc tests on SPSS (Ver. 22) and mean was separated by least significant difference of the different groups. Significant difference was accepted at the level of $P<0.01$.

\section{DISCUSSION}

Phytochemical screening of the methanol extract of the vegetables showed the presence of phenols, flavonoids, alkaloids, cyanide and tannins. Phenol concentration was highest in the vegetables and concentration of tannins were the lowest. Amaranthus hybridus however had the highest concentration of all phytochemicals screened for as presented in Table 1. Phytochemicals present in plants have been well documented to have medicinal and therapeutic activities (Himani et al., 2014).

The percentage (\%) inhibition of DPPH radicals showed that the extract inhibited DPPH in a dose dependent manner as shown in Table 2. From the obtained result, $\mathrm{IC}_{50}$ value for the extract will be slightly above $800 \mu \mathrm{g} / \mathrm{mL}$. Also, Amaranthus hybridus extract showed more activity than Telferia occidentalis. Result obtained for FRAP assay also showed that the extract possesses reducing power and this was in a dose dependent manner, although Amaranthus hybridus was more potent than Telferia occidentalis as shown in Table 3. This result justifies the result of values obtained from the phytochemical screening of the vegetables. As earlier reported, Amaranthus hybridus showed greater concentration of the phytochemicals reported in this study. The ability of the plant extract to reduce $\mathrm{Fe}^{3+}$ to $\mathrm{Fe}^{2+}$ would lie in the antioxidant activity of the plant which is a function of it phenolic, flavonoids and tannin content.

Result for $\mathrm{LD}_{50}$ for cadmium which was administered to Rats as presented in Table 4 showed a value of $212 \mathrm{mg} / \mathrm{kg} \mathrm{B.W}$ when calculated. Signs of toxicity were paralysis, stretching, weakness, dizziness, urination, chocking followed by death within $48 \mathrm{hrs}$ of administration. $\mathrm{LD}_{50}$ value for cadmium obtained from our study is in strong agreement with the $\mathrm{LD}_{50}$ of cadmium reported by Kotsonis and Klaasen, (1997) as $225 \mathrm{mg} / \mathrm{kg}$ of cadmium administered as cadmium chloride in water for Rats.

Cadmium, a potent toxic and heavy metal is constantly present in our environment. It concentration is known to increase in industrialised regions (Ejiofor et al., 2016). It exposure occurs through inhalation or contamination of the food chain (Abernethy et al., 2010). It main target point of toxicity is liver and kidney after absorption. Cadmium induces it deleterious effects through generation of oxidative stress (Matovi'c et al., 2011) and also affect liver functioning and metabolism. Valko et al. (2005) earlier reported that cadmium toxicity induces oxidative stress, promotes lipid peroxidation actively and depletes glutathione.

Result for antioxidant in liver and kidney homogenate (Table 5 and 7) showed that cadmium toxicity promoted the generation of free radicals and progressed to the generation of lipid peroxidation in liver and kidney organs. 
Table 1: Table showing concentration of some phytochemicals $(\mathrm{g} / 100 \mathrm{~g})$ in the plant extract.

\begin{tabular}{cccccc}
\hline & $\begin{array}{c}\text { Flavonoids } \\
(\mathbf{g} / \mathbf{1 0 0 g})\end{array}$ & $\begin{array}{c}\text { Tanins } \\
(\mathbf{g} / \mathbf{1 0 0 g})\end{array}$ & $\begin{array}{c}\text { Cyanide } \\
(\mathbf{g} / \mathbf{1 0 0 g})\end{array}$ & $\begin{array}{c}\text { Alkaloids } \\
(\mathbf{g} / \mathbf{1 0 0 g})\end{array}$ & $\begin{array}{c}\text { Phenols } \\
(\mathbf{g} / \mathbf{1 0 0 g})\end{array}$ \\
\hline Tel. occ. & $1.68 \pm 0.00$ & $0.06 \pm 0.00$ & $0.47 \pm 0.01$ & $3.25 \pm 0.01$ & 0.01 \\
Ama. hyb. & $1.84 \pm 0.01^{\mathrm{a}}$ & $0.15 \pm 0.02^{\mathrm{a}}$ & $0.55 \pm 0.02^{\mathrm{a}}$ & $3.79 \pm 0.04^{\mathrm{a}}$ & \\
\hline
\end{tabular}

${ }^{a}$ significantly $(\mathrm{P}<0.05)$ higher in the same column

values are expressed as mean \pm S.D of triplicate determination

key- Tel. occ. (Telferia occidentalis) Ama. Hyb (Amaranthus hybridus)

Table 2: Table showing result for in vitro antioxidant (DPPH Assay) of plant extract.

\begin{tabular}{cccc}
\hline & Tel. occ. & Ama. hyb. & Ascorbate \\
\hline $25 \mu \mathrm{g} / \mathrm{mL}$ & $12.48 \pm 0.38^{*}$ & $17.52 \pm 0.77^{*}$ & $95.51 \pm 0.32$ \\
$50 \mu \mathrm{g} / \mathrm{mL}$ & $22.31 \pm 0.35^{*}$ & $24.11 \pm 3.43^{*}$ & $95.67 \pm 0.45$ \\
$100 \mu \mathrm{g} / \mathrm{mL}$ & $28.87 \pm 0.10^{*}$ & $31.10 \pm 0.49^{*}$ & $95.74 \pm 0.31$ \\
$200 \mu \mathrm{g} / \mathrm{mL}$ & $30.43 \pm 0.90^{*}$ & $34.60 \pm 0.56^{*}$ & $95.17 \pm 0.27$ \\
$400 \mu \mathrm{g} / \mathrm{mL}$ & $37.32 \pm 0.53^{*}$ & $38.00 \pm 0.79^{*}$ & $94.96 \pm 0.23$ \\
$800 \mu \mathrm{g} / \mathrm{mL}$ & $41.36 \pm 0.45^{*}$ & $43.26 \pm 0.25^{*}$ & $95.74 \pm 0.31$ \\
\hline
\end{tabular}

* significantly $(\mathrm{P}<0.05)$ lower than ascorbate in the same column

key- Tel. occ. (Telferia occidentalis) Ama. Hyb (Amaranthus hybridus)

Table 3: Table showing result for in vitro antioxidant (FRAP) of plant extract.

\begin{tabular}{llll}
\hline & Tel. occ. & Ama. hyb. & Ascorbate $(125 \mu \mathrm{g} / \mathrm{mL})$ \\
\hline $25 \mu \mathrm{g} / \mathrm{mL}$ & $0.29 \pm 0.00^{*}$ & $0.31 \pm 0.07^{*}$ & \\
$50 \mu \mathrm{g} / \mathrm{mL}$ & $0.31 \pm 0.00^{*}$ & $0.31 \pm 0.00^{*}$ & $2.00 \pm 0.00$ \\
$100 \mu \mathrm{g} / \mathrm{mL}$ & $0.33 . \pm 0.00^{*}$ & $0.32 \pm 0.01^{*}$ & \\
$200 \mu \mathrm{g} / \mathrm{mL}$ & $0.36 \pm 0.00^{*}$ & $0.38 \pm 0.04^{*}$ & \\
$400 \mu \mathrm{g} / \mathrm{mL}$ & $0.38 \pm 0.01^{*}$ & $0.41 \pm 0.01^{*}$ & \\
$800 \mu \mathrm{g} / \mathrm{mL}$ & $0.42 \pm 0.01^{*}$ & $0.46 \pm 0.01^{*}$ & \\
\hline
\end{tabular}

* significantly $(P<0.05)$ lower than ascorbate in the same column

key- Tel. occ. (Telferia occidentalis) Ama. Hyb (Amaranthus hybridus)

Table 4: Table showing acute oral toxicity of $\mathrm{Cdcl}_{2}$.

\begin{tabular}{cccc}
\hline & & Acute oral toxicity test after administration of $\mathrm{Cdcl}_{2}$ & Toxicity sign \\
\hline S/No. & Dose $\mathbf{( m g / k g )}$ & Mortality & Paralysis, weakeness, urination, choking, \\
2 & 150 & $0 / 3$ & same as above, followed by death. \\
\hline At & 300 & $1 / 3$ & \\
\hline
\end{tabular}

At $150 \mathrm{mg} / \mathrm{kg}$ B.W dose, paralysis, weakness, frequent urination and chocking were signs of toxicity observed. However, at 300mg/kg B.W, death was recorded.

Table 5: Showing result of antioxidant activity in liver homogenate of test and control animals.

\begin{tabular}{|c|c|c|c|c|}
\hline Group & $\begin{array}{c}\text { MDA } \\
(\mu \text { Mole/mg protein) }\end{array}$ & $\begin{array}{c}\text { SOD } \\
\text { (Unit/g protein) }\end{array}$ & $\begin{array}{c}\text { CATALASE } \\
\text { ( } \mu \text { Mole/mg protein) }\end{array}$ & $\begin{array}{c}\text { GSH } \\
(\mu \text { Mole/mg protein) }\end{array}$ \\
\hline $\mathrm{A}$ & $0.07 \pm 0.00$ & $22.08 \pm 2.02^{\mathrm{b}}$ & $49.84 \pm 3.29$ & $20.82 \pm 0.47$ \\
\hline B & $0.20 \pm 0.17$ & $19.48 \pm 1.57^{\mathrm{b}}$ & $41.14 \pm 14.07$ & $21.50 \pm 0.38$ \\
\hline $\mathrm{C}$ & $0.16 \pm 0.19$ & $20.50 \pm 2.18^{b}$ & $57.00 \pm 2.90$ & $21.97 \pm 1.68$ \\
\hline $\mathrm{D}$ & $0.72 \pm 0.05^{\mathrm{a}}$ & $13.58+1.75$ & $42.36+9.91$ & $22.40 \pm 1.11$ \\
\hline $\mathrm{E}$ & $0.42+0.18^{\mathrm{a}}$ & $10.22+2.13$ & $22.82+14.74^{\mathrm{c}}$ & $18.02 \pm 0.49^{\mathrm{c}}$ \\
\hline
\end{tabular}

$\left({ }^{\mathrm{a}}\right)$ - Significantly $(P<0.01)$ higher when compared to other groups in the same column.

$\left({ }^{b}\right)$ - Significantly $(P<0.01)$ higher when compared to group $\mathrm{D}$ and $\mathrm{E}$ in the same column.

(c)- Significantly $(P<0.01)$ lower when compared to other groups in the same column.

The table above showed that GSH and Catalase concentration was significantly $(\mathrm{p}<0.01)$ low in group E compared to group A-D. For SOD, group A-C was significantly higher compared to D and E. For MDA, group D and E were significantly low when compared to group A-C.

Table 6: Showing result of liver function assay of test and control animals.

\begin{tabular}{ccccc}
\hline Group & AST & ALT & ALP & TP \\
(IU/L) & (IU/L) \\
\hline A & (IU/L) & $20.20 \pm 18.75$ & $19.35 \pm 4.65$ & $6.07 \pm 0.74$ \\
B & $15.40 \pm 5.94$ & $45.20 \pm 14.87$ & $37.58 \pm 5.66^{\mathrm{c}}$ & $6.65 \pm 0.56$ \\
C & $19.40 \pm 4.78$ & $44.40 \pm 17.64$ & $30.38 \pm 8.87$ & $7.05 \pm 0.12$ \\
D & $16.80 \pm 4.76$ & $45.94 \pm 13.80$ & $21.13 \pm 3.25^{\mathrm{b}}$ & $7.21 \pm 0.63^{\mathrm{e}}$ \\
E & $17.20 \pm 6.57$ & $60.40 \pm 10.85^{\mathrm{a}}$ & $78.05 \pm 15.75^{\mathrm{a}}$ & $3.72 \pm 0.41^{\mathrm{d}}$ \\
\hline
\end{tabular}

$\left({ }^{\mathrm{a}}\right)$ - Significantly $(P<0.01)$ higher when compared to other groups in the same column.

(b)- Significantly $(P<0.01)$ lower when compared to group B and E in the same column.

$\left({ }^{c}\right)$ - Significantly $(P<0.01)$ higher when compared to group A and D in the same column.

$\left({ }^{d}\right)$ - Significantly $(P<0.01)$ lower when compared to other groups in the same column.

$\left({ }^{e}\right)$ - Significantly $(P<0.01)$ higher when compared to group A and $\mathrm{E}$ in the same column.

Result for ALT and ALP was significantly higher in group E when compared to group A-D. Result for TP was significantly low in group E when compared to A-

D. 
Table 7: Showing result of antioxidant activity in kidney homogenate of test and control animals.

\begin{tabular}{|c|c|c|c|c|}
\hline Group & $\begin{array}{c}\text { MDA } \\
(\mu \text { Mole/mg protein) }\end{array}$ & $\begin{array}{c}\text { SOD } \\
\text { (Unit/g protein) } \\
\end{array}$ & $\begin{array}{c}\text { CATALASE } \\
(\mu \text { Mole/mg protein) }\end{array}$ & $\begin{array}{c}\text { GSH } \\
(\mu \text { Mole/mg protein) }\end{array}$ \\
\hline $\mathrm{A}$ & $0.65 \pm 0.05$ & $18.17 \pm 0.79^{\mathrm{d}}$ & $32.19 \pm 0.74^{\mathrm{b}}$ & $17.80 \pm 1.50$ \\
\hline $\mathrm{B}$ & $0.80 \pm 0.10$ & $16.63 \pm 0.60$ & $28.87 \pm 1.23$ & $16.55 \pm 1.70$ \\
\hline $\mathrm{C}$ & $0.58 \pm 0.26$ & $15.91 \pm 1.19$ & $28.87 \pm 2.21$ & $16.21 \pm 0.62$ \\
\hline $\mathrm{D}$ & $0.69 \pm 0.14$ & $16.51 \pm 1.15$ & $30.85 \pm 1.00$ & $17.04 \underline{+0.77}$ \\
\hline $\mathrm{E}$ & $1.66+1.13^{\mathrm{a}}$ & $10.92+0.54^{\mathrm{c}}$ & $19.90+1.16^{\mathrm{c}}$ & $12.89+0.85^{\mathrm{c}}$ \\
\hline
\end{tabular}

$(\mathrm{a})$ - Significantly $(P<0.01)$ higher when compared to other groups in the same column.

$\left({ }^{b}\right)$ - Significantly $(P<0.01)$ higher when compared to group $\mathrm{B}, \mathrm{C}$ and $\mathrm{E}$ in the same column.

$\left({ }^{c}\right)$ - Significantly $(P<0.01)$ lower when compared to other groups in the same column.

$\left({ }^{\mathrm{d}}\right)$ - Significantly $(P<0.01)$ higher when compared to group $\mathrm{C}$ and $\mathrm{E}$ in the same column.

The table above showed that GSH, SOD and Catalase concentration was significantly (p<0.01) low in group E compared to group A-D. For MDA, group E was significantly high when compared to group A-D.

Table 8: Table showing concentration of creatinine and uric acid in test and control animals.

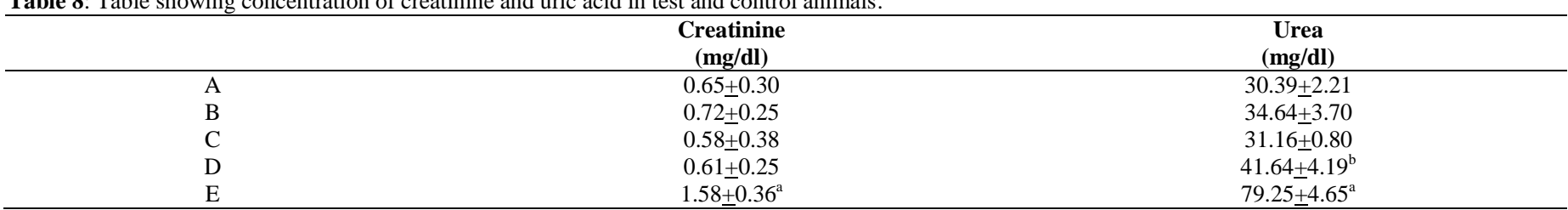

$\left({ }^{a}\right)$ - Significantly $(P<0.01)$ higher when compared to other groups in the same column.

$($ b)- Significantly $(P<0.01)$ higher when compared to groups A and C in the same column.

Urea and Creatinine concentration was significantly high in group $\mathrm{E}$ when compared to group A-D.

This resulted in decrease of antioxidant enzymes, catalase (CAT), superoxide dismutase (SOD) and glutathione (GSH). GSH concentration was significant $(P<0.01)$ lower in group $\mathrm{E}$ when compared to other group (A-D) in both liver and kidney homogenates. Transport of cadmium to the liver and kidney requires albumin as a potent carrier. Once in the liver, cadmium binds to GSH and is transported to the bile where it can be excreted. The significant $(P<0.01)$ increase in the groups $(\mathrm{B}-\mathrm{D})$ administered the vegetables when compared to the group administered cadmium alone without treatment indicated the vegetables promoted the synthesis of GSH and promoted it activities.

Result for SOD and CAT showed that cadmium treatment decreased the concentration of these enzymes in liver and kidney tissues. This is an indication of oxidative stress generated by cadmium in the tissues. Shagirtha et al. (2011) observed cadmium causes oxidative stress, leading to an increase in oxidative stress biomarker, depletion of antioxidant enzymes and also disturbances in membranes structures. SOD and CAT must work collectively to achieve their purpose (Bakirel et al., 2008). SOD dis-mutation of superoxide anion into hydrogen peroxide and oxygen. CAT breaks down hydrogen peroxide, a potent precursor for generation of free radicals to water and oxygen (Kaushik and Aryadeep, 2014) protecting biological system from oxidative damage. Wijeratne, (2005) reported that hydrogen peroxide can lead to membrane and DNA damage. Administration of the vegetables increased the concentration of these antioxidant enzymes in both liver and kidney homogenates and also upregulated their activities.

Lipid peroxidation biomarker, malondialdehyde (MDA) increased significantly $(P<0.01)$ in group $\mathrm{E}$ when compared to other groups (A-D). As earlier reported by Shagirtha et al. (2011) cadmium promotes generation of reactive oxygen species (ROS) which are free radicals. These ROS reacts strongly with membrane lipids and leads to lipid peroxidation (LPO) and cell death (Wijeratne, 2005). LPO affects membrane fluidity, damages membrane structures and proteins, deactivating membrane receptors (Arulselvan and Subramanian, 2007). Administration of the vegetables, controlled positively the oxidative stress induced by cadmium, by preventing lipid peroxidation. The antioxidant ability of the vegetable can be attributed to it rich phenolic contents. Dietary source of polyphenol has been shown to possess scavenging ability for superoxide anion in biological system (Emmanuel et al., 2015).

Result for liver enzymes in blood serum showed that cadmium induced hepatic damage, and administration of the vegetables was able to either ameliorate the adverse damage induced by cadmium or prevented the damage, indicating that the vegetables possessed hepato-protective ability. As earlier mentioned, cadmium bind with albumin to and successfully enters the liver, where it destroys amino acids in the liver. Once in the liver, metallothionein a protein is made active which binds cadmium and transports it to the kidney for excretion (Bernard, 2008). Cadmium affects liver proteins negatively and also reduces the concentration of these proteins.

Result for ALT and ALP presented in Table 6 was significantly $(P<0.01)$ higher in the group $\mathrm{E}$ when compared to other groups (A-D). During liver damage, the concentration of liver enzymes increases in liver due to increase in membrane permeability and necrosis. These enzymes leak from the damaged cells and find their way in blood, and when assayed for, their blood concentration is bound to increase above normal. 
Administration of the vegetables, protected and promoted normal functioning of the liver under cadmium toxicity. An increase in ALP in group E confirms the hepatotoxic effect of cadmium. In conditions of liver damage, ALP is released into blood stream. This is an indication that cadmium might induce liver carcinogenesis.

Result for total protein (TP) in this study, showed that cadmium administration reduced significantly $(P<0.01)$ the concentration of total protein in group E. however, the vegetables administered singly or combined, increased the concentration of TP. The binding of cadmium and albumin can significantly affect the concentration of total protein in blood. Also, cadmium binds strongly to amino acids once in the liver. This binding may also be responsible for the low concentration of total protein in group E. Decline in total protein concentration is a strong indication of liver disease and furthermore, can lead to immunodeficiency. From this study, it could be suggested that the vegetables promoted the synthesis of GSH, which also binds strongly to cadmium and transports it to the bile for excretion, thereby preventing cadmium from binding to amino acids in the liver.

Result for kidney function parameters (Table 8) showed that the concentration of urea and creatinine were significantly $(P<0.01)$ higher in the group $\mathrm{E}$ when compared to other groups (A-D). Creatinine in the liver where it is synthesized is a breakdown product of creatine phosphate in muscle and serve as biomarker for kidney injury reporting kidney and nephron damage. Creatinine is removed mainly through the kidney, and it concentration in biological systems can be altered by various muscles sizes or decreased muscular activity (Ndukaku et al., 2015).

The increase in creatinine and urea concentration in group $\mathrm{E}$ indicates that cadmium is nephrotoxic. Cadmium in the kidney is bound to metallothionein and the toxic form of cadmium $\mathrm{Cd}^{2+}$ in the kidney reacts with proteins and cellular components. Cadmium toxicity in kidney affects tubular reabsorption capacity and also glomerular filtration.

This leads to a high loss of proteins in urine. Result from this study, clearly showed that the vegetables administered singly or combined improved kidney function as shown by the concentration of urea and creatinine.

From this study, it is clear that cadmium induced oxidative stress in liver and kidney tissue. However, the vegetables play a protective role in ameliorating the harmful effects of cadmium on the kidney and liver tissue. Phytochemical studies indicated that the vegetables are rich in phenolic compounds, which may be responsible for the obtained result of the study. Also, fractionation and identification of bio active compound of the vegetables will be useful in promoting the aim of this study.

\section{ACKNOWLEDGEMENT}

The authors are grateful to Dr. Samuel Onoja, Veterinary Pharmacology Unit, Department of Veterinary medicine, Michael
Okpara University of Agriculture, Umudike, for his technical assistance.

\section{Financial support and sponsorship: Nil.}

Conflict of Interests: There are no conflicts of interest.

\section{REFERENCES}

Tarasub N, Devakul N, Ayutthaya W Effect of curcumin on cadmium-induced hepatotoxicity in rats. Thai. J. Toxicol, 2008; 23: 100107.

Amara S, Douki T, Garrel C, Favier A, Rhouma K, Sakly M, Abdelmelek H. Effect of static magnetic field and cadmium on oxidative stress and DNA damage in rat cortex brain and hippocampus. Toxicol. Indian. Health, 2011; 27: 99-106.

Yuan Y, Jiang C, Xu H, Sun Y, Hu F, Bian J. Cadmiuminduced apoptosis in primary Rat cerebral cortical neurons culture is mediated by a calcium signalling pathway. PLoS ONE, 2013; 8: e64330.

Ejiofor UE, Omeh YN, Ebhohon SO. Evaluation of heavy metals content of water bodies at two industrial communities of Eleme and Ewekoro, Southern Nigeria. Nature Environment and Pollution Technology, 2016; 15: 789- 798 .

Järup L, Hellström L, Alfvén T, Carlsson M, Grubb A, Persson B. Low level exposure to cadmium and early kidney damage: the OSCAR study. Occup. Environ. Med. 2000; 57: 668- 672.

Lopez, E, Figueroa, S, Oset-Gasque, MJ, Gonzalez, MP. Apoptosis and necrosis: two distinct events induced by cadmium in cortical neurons in culture. British Journal of Pharmacology. 2003; 138: 901-911.

Ekaiko M, Arinze A, John W, Ajah O. Antimicrobial effect of the leaf extract of psidium guajava L. and Carica papaya L. International Journal of Life Sciences Research, 2015; 3: 55- 60.

Akoroda M. Ethnobotany of Telferia occidentalis (Curcurbitacae) among Igbos of Nigera. Economic Botany, 1990; 12: 29 39.

Alada A. The haematological effects of Telfairia occidentalis diet preparation. Afr. J. Biomed Res 2000; 3: 185- 186.

Okoli B, Mgbeogu C. Fluted pumpkin, Telfairia occidentalis; West African vegetable crops. Econ. Bot. 1983; 37: 145- 146.

Emebiri L, Nwufo M. Pod Rots of Fluted Pumpkin (Telfairia Occidentalis Hook. F.) in Imo State, Nigeria. International Biodeterioration, 1990; 26: 63-68.

Badifu G. Food Potentials of Some Unconventional Oilseeds Grown in Nigeria - a Brief Review. Plant Foods for Human Nutrition, 1993; 43: 211-24

Aderogba MA, Bezabih M, Abegaz BM. Antioxidant constituent of Telferia occidentalis leaf extract. Ife Journal of Science, 2009; 10: 268- 271

Culpepper A, Grey T, Vencill W, Kichler J, Webster T, Brown S. Glyphosate-resistant Palmer amaranth (Amaranthus palmeri) confirmed in Georgia. Weed Science, 2006; 54 620- 626.

Suffo AKL, Ashish R, Tedonkeng PE, Kuiate JR. Effect of Processing Methods on Chemical Composition and Antioxidant Activities of Two Amaranthus sp. Harvested in West Region of Cameroons. J. Nutr. Food Sci., 2016; 6: 477.

Sukhdev S, Suman P, Gennaro L, Dev R. Extraction techniques for medicinal and aromatic plants. International Center for Science and High Technology, 2008

Harborne J. Phytochemical Methods, Chapman and Hall, Ltd., London, 1973; 49 - 188

Edeoga H, Okwu D, Mbaebie B. Phytochemical constituents of some Nigerian medicinal plants. African Journal of Biotechnology 2005; 4: $685-688$

Mensor L, Fabio S, Gilda G, Alexandre S, Tereza C. Screening of Brazilian plants extracts for antioxidants activity by the use of DPPH free radical method. Phytother. Res, 2001; 15: 127-130 
Benzie F, Strain J. Ferric reducing/antioxidant power assay: direct measure of total antioxidant activity of biological fluids and modified version for simultaneous measurement of total antioxidant power and ascorbic acid concentration. Methods in Enzymology, 1999; 299: 1523.

National Institutes of Health Office of Laboratory Animal Welfare Public Health Service policy on the humane care and use of laboratory animals. Bethesda, MD: NIH, 2002

Reitman S, Frankel S. A colorimetric method for determination of serum glutamate oxaloacetate and glutamic pyruvate transaminase. Am J Clin Pathol, 1957; 128: 56-58

Klein B, Read P, Babson L. Rapid method for the quantitative determination of serum alkaline phosphate. Clinical chemistry, 1960; 6: 269-275.

Atawodi S. Evaluation of the hypoglycaemic, hypolipidemic and antioxidant effects of methanolic extract of "Ata-Ofa" polyherbal tea (A- polyherbal) in alloxan- induced diabetic rats. Drug Invention Today, 2011; 3: 270- 276

Sun Y, Oberley W, Li Y. A simple method for clinical assay of superoxide dismutase. Clinical Chemistry, 1988; 34: 497- 500.

Draper H, Hadley M. Malondialdehyde determination as index of lipid peroxidation. Methods in Enzymology, 1990; 186: 421- 431.

Owen C, Belcher R. A colorimetric micro method for the determination of glutathione. Biochemical Journal, 1965; 94: 705-711.

Himani R, Garima S, Nupur J, Neelam S, Navneeta B. Phytochemical importance of medicinal plants as potential sources of anticancer agents. Turkish Journal of Botany, 2014; 38: 1027-1035

Kotsonis F, Klaasen C. Toxicity and distribution of cadmium administered to rats at sublethal doses. Toxicol Appl Pharm, 1977; 41: 667-680

Abernethy D, DeStefano A, Cecil T, Zaidi K, Williams R. Metal impurities in food and drugs. Pharmaceutical Research, 2010; 27: $750-755$

Matovi'c V, Buha A, Bulat Z, Duki'c-Cosi'c D. Cadmium toxicity revisited: focus on oxidative stress induction and interactions with zinc and magnesium. Arhiv za Higijenu Rada i Toksikologiju, 2011; 62: $65-76$

Valko M, Morris H, Cronin D. Metals, toxicity and oxidative stress. Current Medicinal Chemistry, 2005; 12: 1161-1208.

Shagirtha K, Muthumani M, Prabu M. Melatonin abrogates cadmium induced oxidative stress related neurotoxicity in rats. European Review for Medical and Pharmacological Sciences, 2011; 15: 1039-1050.
Bakirel T, Bakirel U, Keles O, Ulgen S, Yardibi H. In- vivo assessment of antidiabetic and antioxidant activities of Rosemary (Rosmarinus officinalis) in alloxan- diabetic rabbits. Journal of Ethnopharmacology, 2008; 116: 39- 42.

Kaushik D, Aryadeep R. Reactive oxygen species (ROS) and response of antioxidnats as ROS- scavengers during environmental stress in plants. Frontiers in Environmental Science, 2014; 2: 53.

Chelikani P, Fita I, Loewen P. Diversity of structures and properties among catalase. Cellular and Molecular Life Sciences, 2004; 61: $192-208$.

Wijeratne S. Hydrogen peroxide induced oxidative stress damage and antioxidant enzyme response in Caco- 2 human colon cells. Journal of Agricultural and Food Chemistry, 2005; 53: 8768- 8774.

Arulselvan P, Subramanian S. Beneficial effects of Murraya koenigii leaves on antioxidant defense system and ultrastructural changes of pancreatic $\beta$-cells in experimental diabetes in rats. Chem Biol Interact 2007; 165: 155-164.

Emmanuel UE, Ebhohon OS, Omeh YN. Effect of fermented and unfermented cocoa bean on some liver enzymes, creatinine and antioxidant in wistar albino rats. Carpathian Journal of Food Science and Technology, 2015; 7: 132-138.

Bernard A. Cadmium and its adverse effects on human health Indian J Med Res, 2008; 128: 557-564

Ndukaku OY, Ejiofor EU, Loveth UE, Oluchi OI. Valuation of some serum kidney functions and lipid profile of malaria patients in South Eastern Nigeria. Rom J Biochem, 2015; 52: 39-49.

\section{How to cite this article:}

Emmanuel EU, Onagbonfeoana ES, Chinedu NP, Chibuike AO, Edith OC, Chioma I, Obinna A, Gavin IC, Raymond IC, Ndukaku OY. Ameliorative effect of methanol extract of Telfairia occidentalis Hook. and Amaranthus hybridus Linn. against cadmium induced oxidative stress in rats. J App Pharm Sci, 2017; 7 (09): 109-115. 